\title{
KARAKTERISTIK MITOS TANAH SERAM
}

\section{Heppy Leunard Lelapary}

Universitas Pattimura

E-mail: leunardlelapary@gmail.com

\begin{abstract}
Abstrak: Mitos tanah Seram adalah potensi cerita rakyat milik masyarakat di Pulau Seram, yang didalamnya terkandung identitas serta pesan kultural kehidupan masyarakat yang mendiami pulau Seram. Sebagai potensi ilmu pengetahuan khususnya tradisi lisan potensi mitos tanah Seram harus dikaji dan mendapat pengayaan aspek keilmuhannya. Mengkaji karakteristik mitos tanah Seram melalui hermeneutika dengan merumuskan konsep mitos tanah Seram, isi mitos tanah Seram, dan tipe-tipe mitos tanah Seram. Diharapkan dapat mendudukan substansi teoretis mitos tanah Seram yang kemudian akan menjadi rujukan kajian dan penelitian lanjutan aspek lain yang terdapat pada mitos tanah Seram.
\end{abstract}

Kata Kunci: Karakteristik, Mitos 


\title{
THE CHARACTERISTICS OF SERAM LAND MYTH
}

\section{Heppy Leunard Lelapary}

Pattimura University

E-mail: leunardlelapary@gmail.com

\begin{abstract}
Abs tract: The Myth of Seram land is the potential of folklore owned by the people on Seram Island, which contains the identity and cultural message of people's lives who inhabit Seram Island. As the potential of science, especially oral traditions, the potential of Seram land myth must be studied and must get enrichment of scientific aspects. Examining the characteristics of Seram land myth through the hermeneutic approach by formulating the concept of Seram land myth, content of Seram land myth, types of Seram land myth is expected to types of spooky land myths is expected to be able to occupy the theoretical substance of Seram land myth, then it will become a reference for further study and research of other aspects that is contained in the Seram land myth
\end{abstract}

Key Words: Characteristics, Myth 


\section{A. PENDAHULUAN}

Masyarakat tanah Seram adalah salah satu etnik Maluku yang mendiami kepulauan Seram. Sampai sekarang ini belum ada sebuah penelitian khusus yang dapat mengemukakan tentang asal-usul penduduk di Maluku. Ada yang mengatakan penduduk di Maluku adalah penduduk asli yang mula-mula mendiami pulau Seram dan kemudian menyebar ke pulau-pulau kecil lain disekitarnya namun ada pula yang mengatakan bahwa pada mulanya pulau Seram itu tidak berpenghuni dan pada suatu ketika datanglah penduduk dari luar yang mendiami daerah itu sehingga merekalah yang menjadi penduduk asli pulau tersebut.

Menurut penelitian geologi pembentukan pulau-pulau di kepulauan Maluku terjadi pada masa Messozoikum dan Neozoikum yaitu antara 150 juta sampai satu juta tahun lalu. Pulau Seram ternyata merupakan pulau yang tertua struktur geologinya. Di masa pleistocean kepulauan Maluku berada di luar daerah dengan daratan Asia dan letaknya lebuh dengan daratan Sahul yang berhubungan dengan benua Australia.

Berdasarkan dugaan para ahli bahwa manusia Wajak daerah pesebarannya sampai di benua Australia yang akhirnya menurunkan ras-ras Austro Melanesia dan Porto Melayu maka diduga besar kemungkinan asal-usul penduduk Maluku yang pertama tiba di pulau Seram adalah keturunan dari ras Autro Melanesi dan Porto Melayu. Mengenai pendapat bahwa memang pulau Seram menurunkan penduduk asli dari pulau itu belum dapat dipastikan mengingat sampai saat ini belum pernah dilakukan penelitian aerkeologis secara sistematis tentang pendapat ini.

Mengenai kata Seram sendiri terdapat beberapa pendapat antara ain Valentyn menyebutnya Selan sebagian masyarakat lokal di daerah Seram Barat menyebutnya Serano (orang tua-tua melafalkan bunyi [r] dan [1] secara bergantian) sedangkan tua-tua adat dari Seram Selatan khususnya di Kecamatan Amahai menyebutnya Seran.

Walaupun belum ada suatu penelitian yang khusus tentang asal-usul penduduk di Maluku apakah penduduk asli atau pendatang dalam kehidupan sehari-hari, orangorang Maluku memiliki sebuah cerita rakyat yang menggambarkan tentang asal-usul nenek moyang mereka. Cerita dimaksud meskipun dianggap mitos tetapi umumnya berkembang sejak dahulu di semua wilayah Maluku. Khusus di Maluku Tengah cerita dimaksud dikenal dengan nama Nunusaku. Diceritakan bahwa Nunusaku adalah sebuah tempat keramat yang menjadi tempat kediaman awal orang-orang asli. Pulau Seram yang dikenal dengan nama orang-orang Alifuru. Nunusaku itu terletak di antara pertemuan tiga batang air atau tiga anak sungai yaitu sungai Tala, sungai Eti dan sungai Sapalewa.

Penduduk asli pulau Seram yang dikenal dengan nama suku Alifuru itu oleh antropolog A.H. Keane disebut sebagai suku Alfuros yang terdiri dari dua suku bangsa yaitu suku Alune dan suku Wemale yang katanya merupakan keturunan campuran bangsa Kaukasus, Mongol dan Papua. Antropolog Sachse dan Taurn berpendapat bahwa suku Alune itu datangnya dari Utara kemungkinan dari Sulawesi Utara dan Halmahera, sedangkan suku Wemale datang dari arah Timur, kemungkinan dari Melanesia. Orangorang Alifuru yang tinggal di pedalaman pulau Seram sendiri tidak menamakan diri mereka sebagai orang-orang Alifuru. Nama itu diberikan dan pengertiannya mengandung arti yang sangat mencemohkan. 
Mitos Tanah Seram adalah sebuah ulasan konseptual terhadap narasi-narasi cerita rakyat yang ada di masyarakat yang secara umum hampir diketahui penceritaannya oleh masyarakat di daerah Maluku. Dalam penulisan ini penamaan mitos Tanah Seram memiliki makna narasi-narasi mitos itu sendiri merupakan satu kesatuan yang melekat dengan kehidupan masyarakat di tanah Seram, memiliki pandangan idiologi kultural masyarakat tanah Seram serta narasi mitos itu menjadi penanda eksistensi wilayah kultural masyarakat tanah Seram.

Mitos dalam perkembangan penelitian di daerah Maluku belum terlalu banyak yang terdokumentasikan. Mitos secara praktis masih menjadi narasi-narasi rakyat Maluku yang masih dituturkan pada kalangan terbatas dan banyak yang belum terpublikasikan. Penulisan ini merupakan kajian awal fenomena mitos di Maluku terbatas pada analisis karakteristiknya.

Sebagai hasil penelitian, untuk pertama kalinya mitos di daerah Maluku diteliti pada tahun 2005 oleh Florence Sahusilawane dan didokumentasikan oleh Kementerian Kebudayaan dan Pariwisata Balai Kajian Sejarah dan Nilai Tradisional Provinsi Maluku dan Maluku Utara, penelitian ini terbatas hanya pada pendokumentasian konten materi cerita-cerita rakyat. Selanjutnya sebagai bentuk pengembangan dari hasil penelitian dimaksud, kajian ini bertujuan untuk mengembangkan cerita-cerita rakyat dimaksud sebagai karakteristik dari mitos yang secara konseptual berdiri sendiri sebagai tipologi mitos daerah Maluku.

Mitos tanah Seram, merupakan produk budaya. Sebagai bentuk tradisi lisan, mitos tanah Seram merepresentasikan dan memanifestasikan sejumlah pesan budaya yang berkaitan dengan tatanan kosmos, identitas diri, dan kepercayaan masyarakat. Didalam dinamikanya, pesan budaya yang menjadi pola bagi tindakan manusia tanah Seram itu berkembang menjadi idiologi yang hegemonik (Barbour,1974; Oden, 1992).

Eksistensi mitos sebagai fenomena budaya dapat dibenarkan dari perspektif mitologi Whitehouse (2002) menegaskan bahwa mitos memiliki nilai yang sangat besar karena memuat kejadian-kejadian historis yang bersifat membuka pandangan dunia mengenai sebuah masyarakat. Bagi Barthes (Budiman, 1999:76), jika diintegrasikan ke dalam sosiologi Durkhim, mitos hampir mirip dengan 'representasi kolektif', Fenomena itu ditunjang oleh temuan para ahli bahwa setiap masyarakat diikat oleh sebuah sistem mitos. Mitos juga mempertahankan hubungan-hubungan sosial masyarakat serta menjadi sarana utama untuk menemukan keabsahan diri suatu kelompok. (Grens, 2001:74).

Keabsahan diri kolektif dapat diperoleh dengan cara menggali makna hakiki mitosnya. Makna mitos diimplementasikan ke dalam bentuk perilaku suatu kolektif. Dalam konsep Eliade (1991:79), perilaku tokoh mitos merupakan tipe bagi perilaku masyarakatnya. Singkatnya mitos memiliki daya untuk mengarahkan perilaku masyarakat. Misalnya kisah gunung Nunusaku di pulau Seram dengan segala selukbeluk penceritaannya di masyarakat.

Mitos memiliki keragaman fungsi. Campbell (Groothius 1989) membagi fungsi mitos menjadi empat bagian, yakni fungsi mistis, fungsi kosmologis, fungsi sosiologis dan fungsi pedagogis. Keragaman fungsi mitos mengindikasikan adanya keragaman tipe atau jenis mitos. Dhavamony (1973:14) membagi ragam mitos berdasarkan aspek 
sarana penciptaannya, yakni mitos penciptaan dalam arti sempit, mitos kosmogonik, mitos asal-usul, dan mitos mengenai para dewa, atau mahkluk adikodrati lainnya, mitos antropogenik, dan mitos yang berkenaan dengan transfoemasi.

Entitas mitos dalam masyarakat tradisi dan representasi makna mitos ke dalam tindakan masyarakat menunjukkan gejala sistem pewarisan mitos. Pewarisan mitos dapat bersifat vertikal dan horisontal (Sudikan, 2001:22). Penuturannya dilakukan pada waktu-waktu tertentu dengan tujuan-tujuan tertentu pula. Pewarisan dapat berlangsung dari generasi ke generasi karena mitos dipercaya terjadi (ada) pada suatu waktu di masa purba dan selalu berpengaruh terhadap dunia dan nasib manusia (Child, 1968:18-19).

Berdasarkan isinya, mitos tanah Seram memiliki ciri-ciri suatu tradisi lisan. Tardisi lisan atau oral lore itu sendiri merupakan bagian integral dari folklor. Beberapa ciri mitos tanah Seram yang masih dapat diidentifikasi antara lain merupakan fenomena sastra yang mengandung nilai-nilai budaya tanah Seram, masih diwariskan secara lisan, memiliki banyak varian dan mempunyai kegunaan bagi komunitas masyarakat Seram. Kenyataan tadi merupakan fenomena kelisanan yang adalah salah satu ciri esensial dari mitos tanah Seram.

Berdasarkan fenomena itu, karakteristik mitos tanah Seram ditinjau dari perspektif tradisi lisan dengan menggunakan ancangan hermeneutika untuk mengupayakan memberikan gambaran yang holistik-etnik tentang bagaimana karakteristik mitos tanah Seram. Kajian ini merupakan kajian awal tentang mitos tanah Seram dengan harapan akan ada penelitian atau kajian lanjutan untuk menyempurnakan kajian mitos tanah Seram. Untuk itu secara berturut-turut dikemukakan tentang tiga subkajian yang dapat memberikan gambaran konsep karakteristik mitos tanah Seram (1) pendasaran istilah mite dan mitos; (2) mitos tanah Seram; (3) tipe-tipe mitos tanah Seram.

\section{B. METODE PENELITIAN}

Metode kajian ini termasuk jenis kajian kualitatif. Hal ini sesuai dengan kajian yang bersifat deskriptif, eksplanatif dan eksploratif, terhadap mitos teks tanah Seram. Baik paparan data, cara penjelasan data, maupun pemahaman data teks tanah Seram dilakukan secara mendalam. Kajian mitos tanah Seram dengan ancangan hermeneutika ini berupaya memberikan gambaran yang holistik-emik tentang bagaimana mitologi mampu mengemas dan melegitimasi falsafah hidup komunitas orang Seram.

Ancangan hermenutika dalam penelitian ini menggunakan pandangan Gadamer, Recoeur dan Habermas sebagai pisau analisis. Dalam konteks hermeneutika, tuturan dalam mitos tanah Seram dipandang sebagai teks yang mencerminkan kehidupan masyarakat Pulau Seram. Struktur mitos tanah Seram, strategi pengungkapan, fungsi serta nilai yang terkandung di dalamnya merupakan gambaram budaya masyarakat pulau Seram.

Dalam menafsirkan makna data, kajian ini mendasarkan pada teknik hermeneutika , yakni (1) distansi dan kelayakan, dan (2) lingkaran pemahaman dan komitmen. Teori tentang distansi dan kelayakan dijabarkan oleh Ricoeur ke 4 aspek, yakni (a) peralihan dari pemahaman tuturan atau peristiwa ke maknanya, (b) pemilihan dari pemahaman atas makna pelaku atau penulis ke makna yang ditemukan, (c) penelaa naskah lepas dari penunjang atau penggantian keluar atau situasi, dan (d) perujukan (referensi) atau 
penafsiran tentang apa yang dituturkan (identifikasi).

Langkah-langkah penafsiran tuturan dan pesan dalam teks mitos tanah Seram dilakukan melalui tahap-tahap pemahaman yang menganut pandangan Ricoeur, yakni pemahaman pada (a) level semantik, (b) level reflektif, dan (c) level eksistensial. Dari pandangan itu, Thompson (2005) menjelaskan bahwa ada beberapa prosedur yang ditempuh Ricoeur dalam menafsirkan makna yakni (a) pemahaman, (b) penjelasan, (c) pengudaraan karya, dan (d) penafsiran. Bertolak dari pandangan tersebut, untuk melakukan penafsiran tentang teks mitos tanah Seram pada langkah awal berusaha memahami struktur, strategi, fungsi, dan nilai-nilai yang terkandung di dalamnya, kemudian berusaha memahami makna pesan tersebut. Setelah memahami maknanya, selanjutya berusaha melakukan telaah terhadap unsur-unsur yang membangun struktur teks mitos tanah Seram, yang meliputi tema-tema teks mitos tanah seram, diksi dan gaya bahasa, strategi pengungkapan, fungsi dalam teks mitos tanah Seram yang meliputi fungsi kultural dan fungsi sosial serta nilai-nilai yang terkandung didalamnya. Pada tahap terakhir menafsirkan makna dan karakteristik teks mitos tanah Seram dengan memanfaatkan data penunjang yang berupa informasi masyarakat yang mengetahui teks mitos tanah Seram dan iktisar dokumen.

Rekonstruksi kondisi yang 'menyebabkan' lahirnya tindakan orang Seram (Thompson, 1993:310). Caranya dengan melakukan analisis terhadap konteks sosial budaya yang menghasilkan dan merepresentasikan orang Seram tersebut. Pemanfataan ancangan hermeneutika dalam kajian ini diharapkan menjadi sumber awal sekaligus tindakan jangka panjang merekonstruksi mitos tanah Seram dalam kajian maupun penelitian pengembangan di masa-masa yang akan datang.

\section{PEMBAHASAN}

\section{Pendarasan Istilah 'Mite' dan 'Mitos'}

Istilah mitos berasal dari bahasa Yunani 'muthos', yang secara harafiah diartikan sebagai 'cerita atau sesuatu yang dikatakan seseorang'. Awalnya mitos dilawankan dengan 'logos'. Dalam konsep ini 'mitos' merupakan cerita yang dikarang seorang penyair, sedangkan 'logos' adalah laporan yang dapat dipercaya. Dalam bahasa Portugis dikenal kata 'mito', sedangkan dalam bahasa Perancis: mythe, yang maknanya tidak berbeda dengan pengertian myth dalam bahasa Inggris.

Dalam bahasa Inggris dikenal istilah 'mythos, atau 'myth' dalam antropologi budaya diartikan sebagai cerita suci berbentuk simbolis yang menyangkut asal-usul dan perubahan-perubahan alam raya dan dunia, dewa-dewi, kekuatan-kekuatan adikodrati, manusia pahlawan dan masyarakat. Claudia Levi-Strauss mendefinisikan mitos suatu warisan bentuk cerita tertentu dari tradisi lisan yang mengisahkan dewa-dewi, manusia pertama, binatang dan sebagainya (Cremers 1977:138)

Istilah 'mite' dalam pengertian sastra mengacu pada salah satu jenis prosa rakyat (lama) yang bercerita tentang dewa-dewi atau pahlawan zaman dahulu (Hartoko \& Rahmanto, 1998:89) Penggunaan istilah mite dalam studi sastra dianggap mendapat pengaruh dari bahasa Belanda mite dan orang Belanda menyerapnya dari bahasa Perancis: mythe.

Dalam sastra Indonesia, penggunaan 'mite' kelihatannya lebih dominan dari pada 
mitos. Namun, kelihatannya tidak ada perbedaan makna 'mite' dalam pengertian sastra dan 'mitos' dalam pengertian antropologi budaya. Pengertian yang diacu oleh kedua istilah tersebut sama, meskipun berasal dari bahasa yang berbeda-beda. Teori-teori yang lazim dipergunakan untuk genre ini lebih banyak bersumber pada literatur Barat yang lebih mengenal 'mitos' dari pada 'mite', terlihat bahwa penggunaan istilah mitos lebih dominan dalam studi humaniora, yang akhirnya berpengaruh juga pada studi sastra.

Dalam penulisan ini, istilah mite dan mitos mengacu kepada makna yang sama, yakni suatu genre prosa. Baik mite maupun mitos dibatasi sebagai sebuah cerita suci yang menyangkut asal-usul dan perubahan-perubahan alam raya dan dunia, dewa-dewi, kekuatan asal-usul dan perubahan alam raya dan dunia, dewa-dewi, kekuatan adikodrati, manusia pahlawan, dan masyarakat yang diwariskan secara turun-temurun dengan menggunakan simbol-simbol tertentu. Whitehouse (2002) secara tegas mengatakan bahwa mitos merupakan dongeng yang sangat besar nilainya. Mitos diartikan sebagai sebuah cerita tradisional mengenai kejadian-kejadian historis yang bersifat membuka pandangan dunia mengenai sebuah masyarakat atau menjelaskan suatu praktek, keyakinan, atau gejala alam.

Ada pula dua bentuk prosa lainnya yang memiliki kemiripan dengan mitos, yakni legenda (legend) dan dongeng (foktale). Baik isi mitos, legenda, maupun dongeng memiliki karakteristiknya yang hampir sama. Beberapa diantaranya adalah berisi tentang kepercayaan kolektif, bersifat pralogis, memiliki tokoh manusia biasa atau manusia super, memiliki fungsi tertentu, dan sebagainya. Walaupun demikian, ada ciriciri hakiki tertentu yang membedakan ketiga bentuk prosa rakyat tersebut (Finegan 1992; Danandjaja, 2002). Finegan (1992) mencoba menggambarkan karakteristik setiap bentuk itu dengan mengulas kembali pendapat William R. Bascom sebagaimana tercermin melalui tabel 2.1 berikut ini.

Tabel 1.1 Tiga Bentuk Prosa menurut William R. Bascom (Sumber: Bascom. 1965)

\begin{tabular}{|c|c|c|c|c|c|}
\hline BENTUK & KEPERCAYAAN & WAKTU & TEMPAT & SIKAP & $\begin{array}{c}\text { KARAKTER } \\
\text { PRINSIPIL }\end{array}$ \\
\hline Mitos & Fakta & Masa lalu & $\begin{array}{c}\text { Dunia yang } \\
\text { berbeda }\end{array}$ & Keramat & $\begin{array}{c}\text { Bukan } \\
\text { manusia }\end{array}$ \\
\hline Legenda & Fakta & $\begin{array}{c}\text { Baru, } \\
\text { belum lama }\end{array}$ & $\begin{array}{c}\text { Dunia sehari- } \\
\text { hari }\end{array}$ & $\begin{array}{c}\text { Duniawi } \\
\text { atau } \\
\text { keramat }\end{array}$ & Manusia \\
\hline Dongeng & Fiksi & $\begin{array}{c}\text { Setiap } \\
\text { waktu }\end{array}$ & Di mana saja & Duniawi & $\begin{array}{c}\text { Manusia } \\
\text { bukan manusia }\end{array}$ \\
\hline
\end{tabular}

Tabel 1.1 tadi menandai mitos sebagai bagian dari dogma, yang selalu dianggap suci, dan biasanya digabungkan dengan teologi dan ritual. Dari aspek kepercayaan, mitos dan legenda sama-sama merupakan suatu fakta yang diyakini oleh pemiliknya. Dalam penyikapannya, mitos dianggap keramat, sedangkan legenda bersifat dialektika antara keramat dan duniawi. Pada prinsipnya perbedaan mitos dan legenda ditujukan oleh waktu dan tempat kejadian serta karakter tokoh-tokohnya. Jika dikaitkan dengan dongeng, mitos dan legenda memiliki tingkat kepercayaan masyarakat yang jauh berbeda dengan dongeng. Kendati mengisahkan hal-hal yang ajaib dan sensasional, dongeng kurang diyakini kebenarannya serta tidak terikat waktu dan tempat. 


\section{Mitos Tanah Seram}

Mitos tanah Seram ialah cerita yang dianggap sakral oleh masyarakat tanah Seram dan diyakini terjadi pada masa lampau. Secara tematis, mitos tersebut mengungkap mengenai asal-usul manusia di tanah Seram, dan spiritualitas kosmis pulau Seram. Mitos tersebut menjadi milik masyarakat tanah Seram dan diwariskan secara turun-temurun. Sejalan dengan pandangan Whitehouse dan Malinowski bahwa mitos dianggap sebagai dongeng yang sangat besar nilainya karena mengungkapkan kejadiankejadian historis yang bersifat membuka pandangan dunia kejadian kosmik, asal-usul manusia dan kepercayaan-kepercayaan masyarakat tanah Seram. Cerita ini diyakini sebagai suatu bagian dari identitas masyarakat tanah Seram sehingga sakralitasnya selalu dipelihara dan dalam manifestasinya selalu digabungkan dengan teologi dan ritual. Secara eksklusif kerangka mitologi mengeeksplanasikan persepsi tanah Seram tentang eksistensi spiritualitas Seram, keyakinan dan kearifan ekologisnya.

Ada banyak cerita rakyat yang tersebar di masyarakat tanah Seram. Isinya memiliki kemiripan dengan mitos, akan tetapi dari segi-segi tertentu tidak dapat dikategorikan sebagai mitos. Misalnya ada dongeng tentang asal-usul umbi-umbian yang berasal dari potongan-potongan tubuh Putri Rapiahainuwele dan dari potonganpotongan tubuh itupun ada yang berubah menjadi benda-benda maupun hantu-hantu.

Pada umumnya mitos tanah Seram ditokohi oleh manusia supranatural atau adikodrati, luar biasa, atau pahlawan etnis. Di antara mereka ada yang menjadi sosok manusia keramat atau lazim disebut tuan tanah, tipe manusia memiliki sifat aneh, sakti dan menguasai perkara-perkara gaib. Mereka hadir bersama penyebaran manusia biasa lainnya. Pada suatu ketika, manusia berkekuatan magis ini tiba-tiba raib dan menempati tempat-tempat yang jauh dari keramaian manusia. Dalam anggapan orang-orang Seram, mahkluk luar biasa ini berdiam di puncak-puncak gunung, di dalam goa-goa, di dalam tanah, dan sebagainya. Wujudnya selalu berubah-ubah sesuai dengan oknum yang ditemui. Ada pula tokoh mahkluk yang bukan manusia tetapi memiliki sifat-sifat manusia, yakni berujud binatang. Perilaku tokoh-tokoh tersebut dianggap sebagai bagian dari suatu dogma yang dianggap suci dan biasanya digabungkan dengan teologi dari ritual orang Seram serta spiritual kosmis.

Peristiwa-peristiwa dalam mitos tanah Seram terjadi pada masa lalu dan selalu berkaitan dengan ritus. Misalnya ritus-ritus pelantikan raja, ganti atap atau bangun rumah baileo. Peristiwa-peristiwa ini dirangkai secara progresif (alur maju) dan dikondisikan dalam latar yang lokalis dan akurat sesuai konteks budaya orang Seram. Pada dasarnya latar mitos tanah Seram dapat dibagi ke dalam 3 kategori, yakni latar tempat, latar waktu dan latar situasi.

Pada zaman dahulu, penuturan mitis hanya dilakukan kepada orang-orang tertentu. Setiap klan memiliki cerita mitosnya sendiri-sendiri dan anggota dari klan lain dilarang menceritakan mitos klan lain. Sekarang ini aturan penuturan mitos pada orangorang tertentu sudah agak longgar. Kendati demikian aturan mengenai hak bertutur setiap klan masih tetap dilanggengkan sampai sekarang ini.

Berdasarkan ketentuan tadi ditemukan lima belas teks mitos tanah Seram yang beredar di masyarakat Seram, yakni (1) Putri Hainuwele (MTS01), (2)Asal Mula Patasiwa dan Patalima(MTS02), (3) Perang Patasiwa dan Patalima,(MTS03), (4) Asal 
Mula Umbi-Umbian, (MTS04), (5) Hewan dan Hantu,(MTS 05) (6) Laba-Laba Emas,(MTS06,) (7) Kerajaan Orang-Orang Alifuru,(MTS07), (8) Sultan Hua Dari Tanah Sebrang,(MTS08), (9) Gurita Laut Sarina (MTS09), (10) Kerajaan Sahulau (MTS10), (11) Anak Raja Jailolo,(MTS11), (12) Putri Bunga Rapiele (MTS12), (13) Asal Mula Nama Seram,(MTS13), (14) Yongker,(MTS14) dan (15) Asal Mula Raja Iha(MTS15).

\section{Isi Mitos Tanah Seram}

Mitos tanah Seram, berisi pengetahuan masyarakat tradisi Seram mengenai keberadaannya di Seram, aturan-aturan mengenai kosmologis Seram, dan kepercayaankepercayaan suku. Pengetahuan masyarakat tradisi tadi dikelompokkan ke dalam beberapa tema mayor. Tema mitos tanah Seram merupakan ide cerita atau gagasan sentral hendak disampaikan masyarakat Seram zaman dahulu kepada generasi penerusnya. Hal itu berupa kisah tentang kejadian alam semesta, kejadian manusia, asalusul sesuatu, tindakan para dewa atau mahkluk adikodrati, dan sebagainya. Yang merupakan akumulasi pengetahuan dan pengamatan nenek moyang orang Seram terhadap kehidupan.

Secara tematis, mitos tanah Seram dibangun oleh tiga tema Mayor, yakni (1) tema asal usul manusia Seram, (2) tema spititualitas kosmis Seram, dan (3) tema manusia dewa atau adikodrati.

\section{Tipe -Tipe Mitos Tanah Seram}

Pada dasarnya tipe sebuah mitos ditentukan berdasarkan naratives elements atas unsur-unsur suatu cerita. Istilah yang populer dalam folkor ialah motif cerita. Motif suatu mitos adalah unsur suatu cerita mitos yang menonjol dan tidak biasa sifatnya (Danandjaya, 2002:53) Konteks penelitian ini membatasi tipe mitos tanah Seram sebagai jenis-jenis mitos ditentukan berdasarkan tema mayor dan unsur-unsur cerita yang menonjol pada setiap varian mitos tanah Seram.

Menurut klasifikasi indeks motif Thompson (dalam Danandjaya 2002:54), motif-motif mitos di dunia diklasifikasikan ke dalam 13 jenis yakni (1) creator, (2) Gods, (3) demigods and culture hero, (4) cosmogony and cosmology, (5) topographycal features of the earth, (6) world calamities, (7) estabilishment of natural order, (8) creation and ordering of huma life, (9) creation of animal life, (10) animals characteristic, (11) origin of trees and plants, (12) origin of plants characteristic, dan (13) miscellaneous explanations.

Mariasusai Dhavamony (1973:14) yang dipengaruhi oleh konsep mitologi Mircea Eliade, membagi ragam mitos berdasarkan aspek saran penciptaannya. Berdasarkan dimensi ini, mitos digolongkan ke dalam enam tipe, yakni (1) mitos penciptaan dalam arti sempit; (2) mitos kosmogonik; (3) mitos asl-usul; (4) mitos mengenai para dewa atau mahkluk adikodrati lainnya; (5) mitos antropogenik; (6) mitos yang berkenan transformasi.

(1) Mitos penciptaan (dalam arti sempit), adalah mitos yang menceritakan penciptaan alam semesta yang sebelumnya tidak ada. Mitos ini melukiskan penciptaan dunia lewat pemikiran, sabda, atau usaha dari seorang dewa. 
(2) Mitos Kosmogonik, merupakan mitos yang mengisahkan penciptaan alam semesta melalui sarana yang sudah ada atau lewat perantara. Mitos ini memiliki beberapa ragam, yakni (1) mitos-mitos yang menyoroti pengalaman kosmogonik; (2) mitos-mitos yang melukiskan penciptaan lewat cara pemilaa zat-zat primordial yang mulanya tak terbedakan; (3) mitos-mitos yang melukiskan peristiwa kosmogonik sebagai akibat penyembelihan manusia pertama atau raksasa laut Ophidia.

(3) Mitos asal-usul, adalah mitos-mitos yang mengisahkan asal mula atau awal dari segala sesuatu, seekor binatang, suatu jenis tumbuhan, sebuah lembaga, dan sebagainya.

4) Mitos mengenai para dewa atau mahkluk adikodrati, ialah mitos yang megisahkan tindakan para dewa atau mahkluk adikodrati lainnya dalam melanjutkan dan melengkapi proses penciptaan yang telah dilakukan oleh Yang Maha Tinggi.

(5) Mitos Antorpogenik, adalah mitos yang berkaitan dengan kisah terjadinya manusia yang mencakup materi-materi pembentuknya.

6) Mitos Transformasi, adalah mitos yang mengisahkan perubahan-perubahan dunia dan manusia di kemudian hari.

Dalam penulisan ini, pendapat Dhavamony tadi digunakan sebagai pijakan untuk menentukan tipe-tipe mitos tanah Seram. Klasifikasi tadi tidak dianggap sebagai harga mati karena dipakai sebagai suatu bahan bandingan dalam merumuskan klasifikasi yang tepat bagi mitos-mitos tanah Seram.

Tipe-tipe mitos tanah Seram ditentukan berdasarkan analisis secara cermat terhadap isi setiap varian mitos dan pengaruhnya didalam masyarakat. Kedua domain ini diperoleh melalui informasi tekstual yang tersurat maupun tersirat. Hasil analisis tersebut selanjutnya dikaitkan dengan teori pengklasifikasian mitos oleh Mariasusai Dhavanmony.

Simpulan tipe-tipe mitos yang tepat dilakukan dengan memadukan hasil analisis dengan teori tipe mitos secara umum. Teori tipe-tipe mitos oleh Mariasusai Dhavamony (1973) bersifat sebagai pembanding untuk merumuskan tipe-tipe mitos tanah Seram. Langkah-langkah ini diambil berdasarkan asumsi bahwa mitos tanah Seram memiliki karakteristiknya sendiri.

Sumber data karakteristik tipe mitos ialah 15 teks lisan mitos tanah Seram yang beredar di masyarakat tanah Seram, yakni Nunusaku, Putri Hainuwele (MTS01), Asal Mula Patasiwa dan Patalima(MTS 02), Perang Patasiwa dan Patalima,(MTS03), Asal Mula Umbi-Umbian, (MTS04), Hewan dan Hantu,(MTS 05) Laba-Laba Emas, (MTS06,) Kerajaan Orang-Orang Alifuru,(MTS07), Sultan Hua Dari Tanah Sebrang,(MTS08), Gurita Laut Sarina (MTS09), Kerajaan Sahulau (MTS10), Anak Raja Jailolo,(MTS11), Putri Bunga Rapiele (MTS12), Asal Mula Nama Seram,(MTS13), Yongker,(MTS14) dan Asal Mula Raja Iha(MTS15). Hasil analisis menujukan kelima belas teks mitos tadi dapat dikategorikan ke dalam 5 tipe yakni (1) mitos penciptaan dalam arti sempit; (2) mitos kosmogonik; (3) mitos asal-usul; (4) mitos mengenai para dewa atau mahkluk adikodrati lainnya; (5) mitos antropogenik; (6) mitos yang berkenan transformasi. Hasil analisis tipe 15 teks mitos tanah Seram tersebut nampak pada tabel 1.2 berikut.

Tabel 1.2 Hasil Analisis Tipe Mitos Tanah Seram

\begin{tabular}{|l|l|l|l|}
\hline No & Mitos & Penggalan Mitos & Tipe \\
\hline
\end{tabular}




\begin{tabular}{|c|c|c|c|}
\hline No & Mitos & Penggalan Mitos & Tipe \\
\hline 1. & Nunusaku (MTS01) & $\begin{array}{l}\text { Di Nunusaku terdapat banyak } \\
\text { keindahan anatara lain alamnya } \\
\text { berbunga, negerinya ilang-ilang (tiba- } \\
\text { tiba raib) terdapat berbagai jeis pohon } \\
\text { dan binatang dari seluruh dunia. Di } \\
\text { negeri itu terdapat berbagai keturunan } \\
\text { manusia dari seluruh suku bangsa yang } \\
\text { ada di dunia. Kehidupan di sana penuh } \\
\text { dengan kedamaian }\end{array}$ & $\begin{array}{l}\text { Mitos asal- } \\
\text { usul }\end{array}$ \\
\hline 2. & $\begin{array}{l}\text { Putri Rapia Hanuwele } \\
\text { (MTS02) }\end{array}$ & $\begin{array}{c}\text { Tiga hari kemudian ia kembali lagi dan } \\
\text { dilihatnya darah yang menetes di atas } \\
\text { daun-daun kelapa dan bunga-bunga } \\
\text { kelapa itu telah berubah menjadi } \\
\text { seorang manusia }\end{array}$ & $\begin{array}{c}\text { Mitos } \\
\text { Antropogenik }\end{array}$ \\
\hline 3. & $\begin{array}{l}\text { Asal Muasal Patsiwa } \\
\text { dan Patalima(MTS03) }\end{array}$ & $\begin{array}{l}\text { Sejak saat itu situasi keamanan di } \\
\text { daerah sekitar Tamene Siwa menjadi } \\
\text { daerah yang tidak amanakibat sering } \\
\text { kali terjadi pembunuhan di antara } \\
\text { kelompok-kelompok yang membunuh } \\
\text { Hainuwele. Terbentuklah dua kelompok } \\
\text { masyarakatyang baru yaitu kelompok } \\
\text { patalima dan kelompok patasiwa atau } \\
\text { kelompok lima dan kelompok sembilan }\end{array}$ & Mitos asal-usul \\
\hline 4. & $\begin{array}{l}\text { Perang Patasiwa dan } \\
\text { Patalima(MTS04) }\end{array}$ & $\begin{array}{c}\text { Muluna Satine mendengarkan } \\
\text { pengaduan Ameta kemudian terbang di } \\
\text { atas pintu gerbang yang dibuat oleh } \\
\text { Ameta itu sambil membawah kedua } \\
\text { lengan Hainuwele. Ia memerintahkan } \\
\text { semua manusia yang ada di bawah } \\
\text { kekuasaannya untuk datang berkumpul } \\
\text { di depan pintu gerbang itu dan mulai } \\
\text { memisahkan mereka dalam dua } \\
\text { kelompok. Siapa yang melewati pintu } \\
\text { gerbang sebelah kiri harus melewati } \\
\text { limabuah bambu runcing dan } \\
\text { orangtersebut masuk dalam kelompok } \\
\text { lima dan tinggal di dunia sampai } 50 \\
\text { tahun sedangkan yang melewati pintu } \\
\text { gerbang sebelah kanan harus } \\
\text { melompati sembilan buah bambu } \\
\text { runcing, masuk dalam kelompok } \\
\text { patasiwa dan akan hidup di dunia } \\
\text { sampai beruis } 90 \text { tahun }\end{array}$ & $\begin{array}{c}\text { Mitos Para } \\
\text { dewa /mahkluk } \\
\text { adikuadrati }\end{array}$ \\
\hline 5. & $\begin{array}{c}\text { Asal Mula Umbi- } \\
\text { Umbian, Hewan dan } \\
\text { Hantu(MTS05) }\end{array}$ & $\begin{array}{c}\text { Dilain pihak keanehanpun terjadi } \\
\text { potongan-potongan tubuh Hainuwele } \\
\text { yang ditebarkan oleh ayhanya berubah } \\
\text { menjadi berbagai jenis benda maupun } \\
\text { umbi-umbian yang waktu itu belum ada }\end{array}$ & $\begin{array}{c}\text { Mitos } \\
\text { Kosmogonik }\end{array}$ \\
\hline
\end{tabular}




\begin{tabular}{|c|c|c|c|}
\hline No & Mitos & Penggalan Mitos & Tipe \\
\hline & & di pulau Seram & \\
\hline 6. & $\begin{array}{l}\text { Laba-Laba Emas } \\
\text { (MTS06) }\end{array}$ & $\begin{array}{c}\text { Laba-laab raja mas memiliki wilayah } \\
\text { kekuasaan yang terbentang luas yaitu } \\
\text { dari wilayah timur sampai ke barat } \\
\text { dimana hampir setiap hari binatang } \\
\text { tersebut terbang kesana dan kemari } \\
\text { mengawasi wilayahnya }\end{array}$ & $\begin{array}{l}\text { Mitos Para } \\
\text { Dewa/ } \\
\text { Mahkluk } \\
\text { Adikodrati }\end{array}$ \\
\hline 7. & $\begin{array}{l}\text { Kerajaan Orang-Orang } \\
\text { Alifuru(MTS07) }\end{array}$ & $\begin{array}{l}\text { Menurut cerita wilayah yang ditempati } \\
\text { oleh orang-orang Alifuru adalah } \\
\text { dipusat bumi atau yang disebut Tanah } \\
\text { Bungsu yang dinamakan juga Keramat } \\
\text { Kalam Alam Masyhur Alam Jadi. }\end{array}$ & $\begin{array}{l}\text { Mitos Asal } \\
\text { Usul }\end{array}$ \\
\hline 8. & $\begin{array}{l}\text { Sulatan Hua dari Tanah } \\
\text { Sebrang(MTS08) }\end{array}$ & $\begin{array}{c}\text { Sultan Hua adalah seorang raja dari } \\
\text { negeri Ud di tanah Arab...Sultan Hua } \\
\text { membangun sebuah pemerintahan di } \\
\text { sana dan kemudian menikah lagi } \\
\text { dengan tiga orang perempuan dari } \\
\text { Nunusaku...Setelah menikah Sultan } \\
\text { mendapat gelar baru yaitu sultan } \\
\text { Ambon Luak. Sultan Hua membangun } \\
\text { istananya di Buano dan meninggal di } \\
\text { sana.Kuburannya berada di atas } \\
\text { Gunung Hatumahu }\end{array}$ & $\begin{array}{c}\text { Mitos } \\
\text { Transformasi }\end{array}$ \\
\hline 9. & $\begin{array}{c}\text { Gurita Laut } \\
\text { Sarina(MTS09) }\end{array}$ & $\begin{array}{l}\text { Gurita Laut Sarina adalah jelman dari } \\
\text { seorang putri yang dikutuki oleh orang } \\
\text { tuanya yang tinggal di Nunusaku dan } \\
\text { menjadi seekor binatang laut gurita. } \\
\text { Binatang laut itu memiliki kekuasaan di } \\
\text { seluruh lautan di kepulauan Malukui } \\
\text { dan oleh sebab itu ia sangat dihormati } \\
\text { oleh orang-orang alifuru karena } \\
\text { dianggap sebagai penguasa laut }\end{array}$ & $\begin{array}{c}\text { Mitos para } \\
\text { dewa/mahkluk } \\
\text { adikodrati }\end{array}$ \\
\hline 10. & $\begin{array}{c}\text { Kerajaan } \\
\text { Sahulau(MTS10) }\end{array}$ & $\begin{array}{l}\text { Ketika ia telah menjadi raja besar di } \\
\text { Sahulau sanak saudara dari negeri } \\
\text { asalnya datang berkunjung dan } \\
\text { sekaligus menetap di sana. Oleh sebab } \\
\text { itu kerajaan ini memiliki penduduk yang } \\
\text { banyak berasal dari negeri Buton. }\end{array}$ & $\begin{array}{c}\text { Mitos } \\
\text { Transformasi }\end{array}$ \\
\hline 11. & $\begin{array}{c}\text { Anak Raja } \\
\text { Jailolo(MTS11) }\end{array}$ & $\begin{array}{l}\text { Putra-putra sultan mulai berpencar- } \\
\text { pencar. Satu diantaranya adalah } \\
\text { Jamilu. Ia berangkat dari Jailolo dan } \\
\text { tiba di Pulau Ambon. Di sana ia } \\
\text { membangun sebuah perkampungan dan } \\
\text { pada akhirnya menjadi salah seorang } \\
\text { pemimpin di sana yaitu memerintah } \\
\text { dalam sistem empat perdana Hitu }\end{array}$ & $\begin{array}{c}\text { Mitos } \\
\text { Transformasi }\end{array}$ \\
\hline 12. & $\begin{array}{c}\text { Putri Bulan } \\
\text { Rapiele(MTS12) }\end{array}$ & $\begin{array}{l}\text { Di suatu termpat dipuncak bukit kecil } \\
\text { seorang perawan cantik yang bernama } \\
\text { Rapiele. Oleh karena kecantikannya }\end{array}$ & $\begin{array}{c}\text { Mitos Para } \\
\text { Dewa/Mahklu } \\
\text { k Adikodrati } \\
\end{array}$ \\
\hline
\end{tabular}




\begin{tabular}{|c|c|c|c|}
\hline No & Mitos & Penggalan Mitos & Tipe \\
\hline & & $\begin{array}{c}\text { mataharipun tergoda untuk } \\
\text { mempersuntingnya sebagai istri. }\end{array}$ & \\
\hline 13. & $\begin{array}{l}\text { Asal Muasal Nama } \\
\text { Pulau Seram(MTS13) }\end{array}$ & $\begin{array}{l}\text { Setiap kali berkomunikasi panggilan- } \\
\text { panggilan itu saja yang diketahui dan } \\
\text { lama kelamaan penduduk di sekitar } \\
\text { tempat tinggal lelaki tua pun ikut pula } \\
\text { bertransaksi dan kata selan atau siran } \\
\text { selalu dipakai sebagai sarana } \\
\text { komunikasi...Pada akhirnya sesuai } \\
\text { dengan dialek setempat kata Selan atau } \\
\text { Siran berkembang menjadi Seram }\end{array}$ & $\begin{array}{c}\text { Mitos } \\
\text { Tranasformasi }\end{array}$ \\
\hline 14. & Yongker(MTS14) & $\begin{array}{c}\text { Ternyata putri ini memiliki kesaktian } \\
\text { dan setelah Yongker menikah } \\
\text { dengannya Yongkerpun menjadi sakti. } \\
\text { Diceritakan ia dapat mengarungi lautan } \\
\text { luas dengan menumpang kulit kelapa } \\
\text { atau sehelai serabut kelapa demikian } \\
\text { juga Yongker kebal terhadap berbagai } \\
\text { jenis senjata tajam. }\end{array}$ & $\begin{array}{c}\text { Mitos Para } \\
\text { Dewa.Mahklu } \\
\text { k Adikodrati }\end{array}$ \\
\hline 15. & $\begin{array}{l}\text { Asal Muasal Raja } \\
\text { Iha(MTS15) }\end{array}$ & $\begin{array}{l}\text { Masyarakat mengangap inilah tanda } \\
\text { yang telah diberikan sang penguasa } \\
\text { kepada mereka. Diangkatlah anak } \\
\text { lelaki itu menjadi raja dari negeri Iha } \\
\text { dan sejak saat itu pengangkatan } \\
\text { seorang raja dari negeri Iha haruslah } \\
\text { ditandai dengan sebuah tanda khusus. }\end{array}$ & $\begin{array}{l}\text { Mitos Asal- } \\
\text { Usul }\end{array}$ \\
\hline
\end{tabular}

Dari tabel 1.2 dapat dijelaskan bahwa teks mitos tanah Seram memiliki tipe sebagai berikut: untuk tipe kosmogonik, yang termasuk dalam tipe kosmogonik hanya 1 teks yaitu teks mitos MTS05, yang termasuk dalam tipe asal-usul yaitu teks mitos MTS01, MTS03, MTS07, dan MTS15, yang termasuk dalam tipe mengenai para dewa atau mahkluk adikodrati yaitu teks mitos MTS04, MTS06, MTS09, MTS12, MTS14, yang termasuk dalam tipe antropogenik yaitu teks mitos MTS02 dan yang termasuk dalam tipe transformasi yaitu teks mitos MTS08, MTS10, MTS11, MTS13.

Dengan demikian dari 15 teks mitos tanah Seram yang termasuk dalam tipe mitos kosmogonik hanya 1 teks yaitu teks mitos MTS05, yang termasuk tipe mitos asal-usul sebanyak 4 teks, yaitu MTS01, MTS03, MTS07 dan MTS15, yang termasuk tipe mitos para dewa atau mahkluk adikodrati sebanyak 5 teks, yaitu MTS04, MTS06, MTS09, MTS12, MTS14, yang termasuk tipe mitos antropogenik hanya 1 teks yaitu MTS02, dan yang termasuk tipe mitos transformasi sebanyak 4 teks yaitu MTS08, MTS10, MTS11, MTS13.

Dari keenam tipe mitos yang dirumuskan Dhavamony, teks mitos tanah Seram tidak termasuk dalam jenis teks Mitos penciptaan (dalam arti sempit), adalah mitos yang menceritakan penciptaan alam semesta yang sebelumnya tidak ada. Mitos ini melukiskan penciptaan dunia lewat pemikiran, sabda, atau usaha dari seorang dewa. 


\section{KESIMPULAN}

Mitos tanah Seram adalah cerita yang dianggap keramat oleh orang Seram dan diyakini benar-benar terjadi pada waktu lampau. Secara tematis, mitos tanah Seram mengungkapkan asal-usul manusia Seram, spiritualitas kosmis orang seram dan peran dewa atau adikodrati. Mitos tersebut menjadi milik orang Seram dan diwariskan secara turun-temurun dengan simbol tertentu dan cara yang unik.

Pada dasarnya mitos tanah seram memiliki dimensi historil-kultural tanah Seram yang dibalur dengan sistem tradisi lisan. Mitos tanah Seram merupakan produk budaya yang memanifestasikan suatu aspek dari tatanan kosmik tanah Seram. Fenomena budaya itu dikemas dalam bentuk tradisi lisan yang mengekspos sejumlah pesan budaya dan menjadi model bagi tindakan manusia Seram dalam berinteraksi dengan alam Seram.

Berdasarkan ancangan hermeneutika pandangan Gadamer, Ricouer dan Habermas sebagai pisau analisis kajian terhadap tipe mitos tanah Seram menghasilkan 5 tipe mitos yang tersebar pada 15 teks mitos Tanah Seram yang terindetifikasi sebagai berikut: untuk tipe kosmogonik, yang termasuk dalam tipe kosmogonik hanya 1 teks yaitu teks mitos MTS05, yang termasuk dalam tipe asal-usul yaitu teks mitos MTS01, MTS03, MTS07, dan MTS15, yang termasuk dalam tipe mengenai para dewa atau mahkluk adikodrati yaitu teks mitos MTS04, MTS06, MTS09, MTS12, MTS14, yang termasuk dalam tipe antropogenik yaitu teks mitos MTS02 dan yang termasuk dalam tipe transformasi yaitu teks mitos MTS08, MTS10, MTS11, MTS13.

Kajian ini memberikan cakrawala baru bagi penelitian tradisi lisan Maluku yang telah dilakukan selama ini. Kajian terhadap mitos-mitos dan cerita-cerita rakyat Maluku yang telah didokumentasikan pun dapat memanfaatkan kajian ini untuk dapat dikembangkan. Sebagai kajian awal diharapkan dapat menjadi pintu masuk untuk lakukan penelitian maupun pengembangan konsep mitos tanah Seram maupu mitosmitos lain yang ada di daerah Maluku. 


\section{DAFTAR PUSTAKA}

Barbour, I.G. 1974. Myth, models, and Paradigma: A Comparative Study in Science and religion. New York: Happer and Row Publisher.

Budiman, K. 1999. Kosa Semiotika Yogyakarta:LKIS

Cremers, A.1997. Antara alam dan Mitos. Flores: Nusa Indah

Danandjaya, J. 2002. Folkor Indonesi: Ilmu Gosip, Dongeng, dan lain-lain. Jakarta:Grafiti

Dhavamony, M.1973 Phenomonology of Religion. Roma: Gregorian University Press. Terjemahan oleh Kelompok Studi Agama Driyakarya. 1995 Yogyakarta:Kanasius

Eliade, M.1991. The Myth of the Eternal Return, or Cosmos and history. Terjemahan oleh Cuk Ananta.2002. Yogyakarta: Ikon Teralitera

Grens, S.J. 2001. Tanpa Tahun A Primer on Postmodernism. Terjemahan oleh Wilson Suwanto.2001. Yogyakarta: Yayasan Andi.

Groothius, D.1989. The Power of Myth, Book Review. (Online),

(http://www.iclent.org/pub/resources/text/cri/-jrbl/cri-jrnl02.html) diakses pada tanggal 27 Mei 2020

Malinowski, B. 1995. Myth in Primitive Psychology. Magic, Scienceand Religion. New York

Sahusilawane Florence. 2005. Cerita-Cerita Tua Berlatar Belakang Sejarah Dari Pulau Seram.2005. Ambon: Balai Kajian Sejarah dan Nilai Tradisisonal Provinsi Maluku dan Maluku Utara.

Whitehouse, Deb. 2002 The Use Of Myths In Metafisikal Rekigions: Strategies For Proper Deployment. Paper. Disajikan pasa SSMR Confrensi Regional di Tampa, Florida pada tanggal 27 Oktober 2000 
